\title{
EARNING A LIVING AND ITS POSITION IN THE SACRED LAW: AN EXPOSITION OF SHAYBANI'S ${ }^{1}$ DOCTRINE
}

\author{
Ismail Ya'u Abubakar* \\ Tatiana Danisova** \\ Suleiman Mohammed Hussein Boayo ***
}

\begin{abstract}
Earning a living is considered essential for every human being. The nature of life in this world is based on acquisition and effort; nothing can be obtained miraculously, without effort. God created human beings for a purpose, which is explicated by the Shari'ah. This paper aims to delineate the opinions of Imam Muhammad Shaybani on the earning of wealth, including what should be earned, what the ethics of earning are, and what is the tradition of the prophets concerning the acquisition of a livelihood. The paper highlights the importance of earning, how it maintains one's dignity and brings success in this world and in the hereafter. Finally, the paper affirms that social development can be achieved through earning by knowing what should be kept by those who earn and what should be given by them to the needy. This research is based on a critical and analytical approach to the aforementioned issues in Shaybani's work. Its approach differs from Adi, who only translated al-Kasb, with annotations on important issues.
\end{abstract}

Keywords: Iktisab, doctrine, ethics, hiring, transaction, trade, shaybani, position.

\section{Meaning and Significance of Earning (al-lktisab)}

Earning (al-iktisab) has numerous meanings. According to al-Shaybani, it is obtaining wealth through permissible means; God has made earning a livelihood obligatory upon His servants, so that they may seek assistance by earning through devotional acts. ${ }^{2}$ Ibn Manzur stated that al-kasbu means the earning of wealth. ${ }^{3}$ For Sibawaih, kasb means to act properly and waktsaba means a way of acting and striving. According to al-Mawsu'at al-Kuwaitiyyah al-Fiqhiyah (Encyclopaedia of Jurisprudence of Kuwait), al-kasb means obtaining wealth by any means, either permissible (halal) or prohibited (haram). Moreover, the meaning of vocation (al-ihtiraf) differs from earning because the latter is generally compared to earnings from a vocation, as defined by lexicographers. This condition may not be a custom of a person who earns wealth through a vocation. ${ }^{4}$ In relation to earning, a number of scholars have commented on the following Qur'anic verse, in which God says, 
Allah burdens not a person beyond his scope. He gets reward for that (good) which he has earned, and he is punished for that (evil) which he has earned. "Our Lord! Punish us not if we forget or fall into error, our Lord! Lay not on us a burden like that which you did lay on those before us (Jews and Christians); our Lord put not on us a burden greater than we have strength to bear. Pardon us and grant us forgiveness. Have mercy on us. You are our Maula (Patron, Supporter and Protector etc.) and give us victory over the disbelieving people. ${ }^{5}$

Commenting on the above verse, Ibn Jinni notes that 'makasabat' (He gets reward for that [good] which he has earned) signifies a multiple reward in compensation for one deed, while 'maktasabat' (he is punished for that [evil] which he has earned) is to compensate for only one sin. Ibn Jinni regarded 'makasabat' as profitable earning, while 'maktasabat' is a punishment against him who commits evil. ${ }^{6}$ According to Jurjani, earning is an act which either brings benefit or evil; this should not be attributed to God, as He is free from acquisition of benefit or harm. ${ }^{7}$ However, some theologians have a different opinion, that God created everything, including bad or good actions, though God has attributed good to Himself only. ${ }^{8}$ According to Hans Wehr, it means acquisition or gaining of property or rights by un-interrupted possession of them for a certain period. ${ }^{9}$

The Western perspective holds that all the income of private individuals be categorised into earned or unearned. The difference between these two is that beyond a certain threshold income becomes unearned. Earned income for income tax purposes consists of the following: 1) income from employment, including wages and salary, overtime pay and other rewards of employees; 2) pensions paid to a retired employee, his wife or widow under an accepted pension scheme; and 3) income from a trade or profession to which a person belongs, either as a proprietor or an active partner. Earnings of private individuals also include earnings of companies shared by shareholders. ${ }^{10}$

\section{The Importance of Earning in Islamic Jurisprudence (Fiqh al- Islami)}

Cleansing of the heart is achieved when one earns one's sustenance in a permissible ( halal) manner and uses it to buy only permissible items. Whosoever gives charity from his pure earnings equivalent to date-palms, his reward will be multiplied and uncountable. Islam encourages working for a living because it is a means of establishing right and proper possession. Likewise, Islam gives high regard to manual labour because it is a genuine means of earning, without 
any ambiguity when used properly. ${ }^{11}$ Earning that is meant to gain a livelihood and not accumulate wealth is better than devotional acts as its benefits extend to other people, whereas the benefits of devotional acts are confined to one person. Certainly, the Prophetic traditions affirm that the best of people are those who benefit others. The caliphs during the golden age said that devotion is divided into ten segments, nine parts of which are meant for earning permissible wealth. ${ }^{12}$ Earning is given preference over devotion and perhaps even over fighting in jihad. ${ }^{13}$ Imam Ghazali stresses the obligation of earning, saying:

Working for earning is mandatory since performing the prescribed prayers cannot be done except by doing the ritual purification, and this in turn requires a kettle to pour water with, or leather bucket (dalw), or rope with which to draw water from the well (al-bi'r). Likewise, the prescribed prayers cannot be performed except by covering the naked parts of the body ('awrah), and that is only possible by clothing (thawb) which normally cannot be obtained except by working (for it); and whatever that is required in order to fulfil an obligation is in itself an obligation. ${ }^{14}$

Earning eradicates poverty and prevents begging. It improves standards of living. Earning is part of faith, as faith comprises action. The community is prompted to utilise the resources of the earth in cultivation, making investments and other activities.

In figh al-Sunnah, Sayyid Sabiq stated that the legitimacy of earning through buying and selling is substantiated by the Qur'anic injunction: "But Allah had permitted trade and forbidden usury" (2:275) ${ }^{15}$ and from the Prophetic tradition: "The best earning is what is obtained through the use of our hands and all worthy transactions." Thus, manual labour or contract is the best source of income a person can rely upon, even though others are permissible also. ${ }^{16}$

In the Maliki school of thought, Abu Qasim al-Garnati classified earning into two types: 1) earning without exchange, such as inheritance, spoils of war and gifts; and 2) earnings from buying and selling, hiring, or receiving a dowry in a marriage contract. The first category highlights that earning can be made without any exchange activities or a consideration in return. ${ }^{17}$

In the Hanafi School of thought, Imam al-Shaybani has explained earning as the acquisition of wealth for permissible reasons, which may be found in various aspects of life. God instructed His servants to earn wealth for their livelihood and seek rewards in their devotional acts. The Qur'an states that "And seek the bounty of God: and remember God frequently" (62:10). It should be inferred from this verse that one should seek worldly material gain in order to devote oneself to spiritual acts. ${ }^{18}$ 


\section{Some Commentaries on al-lktisab in the Qur'an}

Before mentioning the Qur'anic commentaries, it is important to note in respect to the term al-iktisab that the present discussion focuses on how many times this word appears in the Qur'an along with its derivatives. According to $M u$ ' jam Alfadz Qur'an al-Karim, kasaba is mentioned sixty-seven times. ${ }^{19}$

According to the commentary of Bagawi, al-kasb means cultivation of good in this world and in the hereafter. The Qur'an says:

To any that desires the tilth of the hereafter, We give increase in his tilth; and to any that desires the tilth of this world, We grant somewhat thereof, but he has no share or lot in the Hereafter $(42: 20){ }^{20}$

Allah also says: "In his favour shall be whatever good he does, and against him whatever evil he does [Laha ma kasabat wa alaiha maktasabat]."21

In view of this verse, al-Zamakshari asserts that a soul benefits from the good it earns and is harmed by the evil it does. No one should carry the burden of another, nor shall anyone be rewarded for another person's devotional act. The same applies to the rewards of good earning; they are confined only to the person who performed them, no one else. Kasaba is confined to good deeds, iktasaba to evil deeds. This is because in al-iktisab there is gain and benefit for oneself. The propensity to evil is an instinct a person has to push them towards evil freely. ${ }^{22}$

In view of the above verse, Muhammad 'Ali al-Sabuni highlights that "every soul shall be rewarded for the good presented and the evil perpetrated." 23 Because of the above verse, Muhammad ibn Jarir al-Tabari explicated that, "every soul shall have what wounded or hurt to itself and what acts for good." In this translation, however, the usage of the term "wounded" is improper as it gives a negative impression; wounding oneself may not bring good to the soul. Instead 'wa alaiha maktasabat' means each soul has the good of what it acts for. ${ }^{24}$ In referring to the previous verse, Abdullahi ibn Abbas commented that "as [a] soul has the good earned and when it leaves self-conversation (hadith al-nafs), forgetfulness, mistake and dislike;" thus 'wa alaiha maktasabat' means that the soul has earned evil with self-centeredness, forgetfulness, mistake or disliking. ${ }^{25}$

In contrast to al-Zamakshari's view, Wahbah al-Zuhaili maintains that the saying of Allah "laha makasabat wa alaiha maktasabat"26 entails that al-iktisab is attached to evil because it necessitates changes, difficulties and planning that violates human nature and customs, but doing good does not need striving because God instilled it in human nature. Thus, the soul gets its pleasure from practising it. $^{27}$

In the Encyclopaedia of Islam, earning is regarded as gainful business, meaning good investment. Human activity has to aim at seeking the pleasure 
of God and the mercy of God, both of which are regarded as better than the riches of this world. The Qur'an tells us that the best way to obtain the pleasure of Allah is to spend in good causes and practice true worship. Good earning may be to release one's debtor if the latter is unable to repay his debt. This is considered as the most gainful business. Moreover, endurance of pain, selfcontrol and fighting in the sake of God also bring returns in this world and the hereafter. The act of performing righteous deeds either by one's action or wealth is considered as qardun hasanun (a benevolent loan). Another element of gainful business is to base one's decision on the consciousness of God without illusion or transgression. According to the Qur'an, the most lucrative gain or business is the one that is not confined to the temporal life of this world but also includes the ever-lasting rewards which are promised to the faithful. Gaining in business through fraud harms the doer in this world while good earnings bring joy and peace in the hereafter. In this manner, the preference for good and lawful business activities over bad and unlawful ones is considered proof of a sound decision. In other words, wisdom lies in judging by quality rather than by quantity.

When determining the best thing to invest in, decisions must be guided by what the Qur'an commands and the Prophet taught. The Qur'an motivates believers to emulate the Prophet in their dealings; doing so is a sure way of gaining the bounties and profits of Allah. Fulfilment of a promise safeguards one's trust, while to be just and moderate is the hallmark of good conduct. Bad practices, such as obtaining wealth through usury, deception and oppression harm individuals and society as a whole. These unworthy acts keep one from the mercy of Allah and decrease one's wealth. ${ }^{28}$ In this way, Imam Ala' al-Din 'Ali ibn al-Lubadi considered a usurious person a looser, saying:

The miserable man imagined that he was saved through his prayer and fasting in spite of his oppression and deceit, but none of that availed him at all. Rather, his good deeds were transferred as restitution to those whom he had oppressed and betrayed, and he himself was cast into fire. ${ }^{29}$

There are similarities and differences between earning (al-kasb) and hiring (ijarah). The Arabic ijarah is derived from the letters ' $a-j-r$ and means a statement of contract between the employee and the employer regarding work to be carried out for an amount of wealth. Hiring without any consideration in return is lending ('iarah). ${ }^{30}$ Hiring has a positive effect in its technical sense, while earning produces both positive and negative effects. For example, the positive effect of hiring is shared by the employer and employee when they enter into a binding agreement. On the other hand, the benefit of earning belongs to the earner only. 


\section{Earning in the Prophetic Tradition}

Al-Shaybani stated, "Earning is the sunnah of the messengers (p.b.u.h.). ${ }^{31} \mathrm{We}$ are commanded to adhere to their teachings and follow their guidance. Indeed, our prophet Adam (p.b.u.h.) was the first person who earned wealth. The Qur'an states, 'So let him not get you both out of the Garden, so that thou art landed in misery...' 32 meaning that 'Adam suffered in earning wealth. Mujahid (r.a.) said the interpretation of the verse [by his own understanding] 'Do not eat bread with oil except by working so hard till you die." ${ }^{33}$ This statement by Mujahid clarifies the verse about Adam, namely that this world is a place of suffering even for the best creation of God, the prophets. It also highlights that it is part of their mission as prophets to seek worldly material goods, in addition to the ultimate purpose of performing devotional acts. By contrast, asceticism denies the lawfulness of earning a living to the extent that even basic duties become difficult to perform. This extremism in asceticism goes beyond torture and is being currently practised by Christians, Buddhists and Hindus. This kind of practice has a negative effect on the betterment of the socio-economic aspects of individual life and society. ${ }^{34}$

Al-Shaybani said, "In the report (athar) it is narrated that when 'Adam (p.b.u.h.) was sent down to earth, Gabriel (p.b.u.h.) brought to him seed and commanded him to plant it. When 'Adam planted and cultivated the seed, he processed it into ground flour and then baked it. After finishing these activities came the time of 'Asr prayer, and Gabriel (p.b.u.h.) came to him and said: 'indeed your Lord is greeting you.' He said: 'if you fast the rest of the day, He will forgive your sin and favour your children.' Then 'Adam fasted, even though he was eager to eat the food in order to compare its taste with the taste of food in Paradise. Since that time, it became a sunnah for people to break their fast after "Asr." 35 This shows that even at the time of Adam, farming was a vocation for sustainable development. The importance of farming cannot be underestimated as it supplies food for man and animals. It also plays a role in providing employment, improving well-being, and developing rural and urban areas. Even developed countries depend on farming and agriculture. ${ }^{36}$

Al-Shaybani said, "Noah (p.b.u.h.) was a carpenter; he used to eat from what he earned. Likewise, Idris (p.b.u.h.) was a tailor. ${ }^{37}$ Meanwhile, Ibrahim (p.b.u.h.) was a merchant as narrated by the Prophet (p.b.u.h.): 'Trade is recommendable on you; indeed, your father was a merchant.' The term 'farther' in the hadith refers to Ibrahim al-Khalil (p.b.u.h.)." 38

In a similar vein, al-Shaybani said, "Dawud (p.b.u.h.) ate from what he earned; indeed it was narrated that he used to go out secretly (mutanakkiran). Then people in his time used to ask about his behaviour until he met Gabriel (p.b.u.h.) one day in the form of a young man, then Dawud (p.b.u.h.) asked Gabriel (p.b.u.h.), O 
you young man how do you know Dawud (p.b.u.h.), then Gabriel said: blessing of Allah be on you, indeed, you have only one habit. Then Dawud asked Gabriel what is that habit, he said, indeed, you usually eat from the treasury, surely the best of you is the one who eats from his earning." ${ }^{\text {"39 }}$ Habibu al-Rahman explicated the role of the public treasury (bayt al-mal) as established during the golden era of Islam, holding it to be an institution for generating funds for the state. Public treasuries are still relevant in contemporary times; they perform the function of a ministry of finance. They also act as a Central Bank by monitoring, controlling and issuing currency. ${ }^{40}$

Al-Shaybani further stated, "Dawud (p.b.u.h.) returned to his mihrab (mosque) supplicating to Allah and saying: O God teach me how I should earn wealth and not rely on the treasury, and then Allah taught him how to make armour-plate, and gave him the skill in softening iron, so iron was soft in his hands just as how the dough was soft in peoples' hands. In this regard, the Qur'an states: '(Also) And We made the iron soft for him. ${ }^{41}$ In another verse, the Qur'an states: 'It was We who taught him the making [of] coats of mail for your benefit, to guard you from each other's violence: will ye then be grateful?' ${ }^{42}$ This episode between Dawud and angel Jibril shows the importance of earning, especially through handcrafts. Dawud (p.b.u.h.), relied on the public treasury for [his] livelihood. After receiving guidance from the angel, he was taught by God [to] make armourplates and was given the skill of softening iron. Later he changed the mode of his acquisition of his earning[s]." ${ }^{43}$

Al-Shaybani added, "Dawud made the metal coats of mail, and he sold each metal coats for twelve thousand. He paid for his food from his earnings and gave out charity. Sulayman (p.b.u.h.) was making baskets from palm leaves to feed himself. Zakariyya (p.b.u.h.) was a carpenter. ${ }^{44}$ 'Isa (p.b.u.h.) was eating from what his mother generated from the weaving of cloth, and he ate from the grain of corn. As for our prophet (p.b.u.h.), he was making his living from rearing animals occasionally. Indeed it was narrated that the prophet (p.b.u.h.) said to his companions: 'I was rearing animals for 'Uqbah bin Abi Mu'ayt and no prophet was sent to the people except that he was a shepherd."'45

The example of Zakariyya demonstrates that even in ancient days carpentry was of great importance. Wood was used by our forefathers in many aspects of life, whether to make fire or build houses and boats. At present, the need for woodworking extends beyond residential purposes to the commercial sector, where various businesses produce finished products made of wood. Similarly, palm leaves have a comparable value given they are used for many different purposes: as writing material, decoration and containers. ${ }^{46}$

Al-Shaybani further said, "In the hadith of Abi Sa'ibah (r.a) he said: 'The Prophet (p.b.u.h.) was my partner, and he was the best partner because he neither 
deceived nor argued.' Moreover, others said: what kind of partnership do you have, and then he said: 'our partnership is on making leather (al-adam). ${ }^{{ }^{47}}$ The prophet worked as a farmer in Jurf ${ }^{48}$ as was stated by Muhammad in the book of farming in order to show that the earning of wealth is the sunnah of the prophet." ${ }^{\prime 9}$ The kind of business conducted between Abi Sa'ibah and the Prophet still exists, namely a partnership of not less than two people, who contribute money, skills and other resources in accordance with the terms of that partnership. ${ }^{50}$

\section{The Usage of al-lktisab in Various Aspects of Life}

Al-Shaybani said, "Indeed, Allah has prescribed his slaves earning for a living that will help them in conducting their spiritual devotions. In line with this, the Qur'an states: 'And seek the bounty of Allah and celebrate the praises of Allah often (and without stint) that ye may prosper." "'51 As mentioned, Allah has made earning a living a means of practicing spiritual devotion. Indeed, the Qur'an states: "O ye who believe! Give the good things which ye have (honourably) earned." 52 This means that one should spend out of one's wealth and resources. According to Ibn Mas'ud and Mujahid, this verse allows one to spend from the permissible wealth one earns through business and vocation.

As the Qur'an states, wealth must be acquired through permissible ways and not otherwise. ${ }^{53}$ Several verses in the Qur'an point to this. For example, "Whatever misfortune happens to you, is because of the things your hands have wrought, and for many (a sin) He grants forgiveness." ${ }^{54}$ This verse clearly refers to obtaining wrong things for oneself as earning. Also, the Qur'an states: "A punishment by way of example, from Allah, for their crime, and Allah is exalted in power." ${ }^{\circ 5}$ Thus, Allah punishes a thief because he committed an offence. It is known that the term (al-kasb) is used for anything good or evil, but when it is used without qualifications, it generally means earning of wealth.

\section{The Two Types of Earning, Their Rules and Classifications}

Al-Shaybani explicated that, "Earning is divided into two categories. The first is earning of oneself. This means acquisitions of what is necessary for livelihood via means of permissible earning, such as farming, trading and vocational skills. The second category includes earning while doing harm to oneself; this means the earning of a person through illegal or impermissible means, for example stealing, fornication and fortune-telling and others. A person who earns for himself is one who seeks the basic permissible things, and a person who earns against himself is an oppressor, for example a thief. 
"According to the position agreed upon by all scholars, the second type of earning is prohibited. The Qur'an states: 'And if anyone earns sin, he earns it against his own soul: for Allah is full of knowledge and wisdom' ${ }^{56}$ and 'if any one earns a fault or a sin and throws it on to one that is innocent, he carries (on himself both) a false charge and flagrant sin." $" 57$

This means that for whosoever commits an offence, the reward for his deed is restricted to him only. No one can bear it on his behalf. The second verse highlights that one should not earn a fault or sin and throw it on innocents, which is a great crime. Consequently, in relation to business, earning is a good conduct, but in relation to crime it is a misfortune and sinful.

\section{The Four Classification of Earning according to al-Shaybani}

Al-Shaybani, in his book al-Kasb, classified earning into four categories as follows: 1) hiring, which is a contract between the employee and the employer, in which the employee will get benefit from the tasks he is given; 2) business (al-tijarah), involving buying and selling with the intention of earning a profit or exchanging wealth to gain profit; 3 ) farming, such as muzara 'ah (share-cropping) contracts in which one party agrees to cultivate crops, with a share of what is cultivated being given to another party who helped fund or otherwise support the cultivation; and 4) handicrafts (al-sina 'ah), which require the knowledge and technical expertise of a particular vocation in order to be practiced.

All these classifications of earning are the same according to the majority of jurists, including Imams Abu Hanifa, Malik, Shafi 'i and Ahmad. ${ }^{58}$

\section{Earning in Terms of its Permission and Prohibition}

Worldly or spiritual rewards must be earned properly. God accepts only what is afforded through rightful possession. Wealth, property or any other possession can only be gained through right, pleasant and acceptable conduct, such as buying and selling and giving gifts. Oppression, stealing and deceit are not proper ways of acquiring possession of something. Islam motivates earning through all permissible ways, warning against laziness, begging and the wanton enjoyment of benefits. ${ }^{59}$ These unworthy attitudes are far from Islam and will lead to prohibited acts. In this manner, Umar bin Khattab said:

One may not leave earning of wealth, and said O Allah enrich me without putting effort toward it. Surely, heavens have never rained either gold or silver. Verily Allah enriches people by themselves via means of earning. ${ }^{60}$ 
Possession or ownership of any form of provision is only achievable through striving. The Qur'an says: “And shake towards thyself the trunk of the palm-tree: it will let fall fresh ripe dates upon thee." ${ }^{\prime 1}$ If earning, in whatever form, is to uplift anybody, prophets and their brethren, saints and pious people should be the first because they were the first to adhere to and apply the commandments of the Shari'ah. Their struggle for a livelihood took place while living in this world and yet pursuing life after death. Imam Ghazali said:

Common sense (al-ma'qul) attests to it, for in earning resides the order of the world ( $f$ al-kasb nizam al- 'alam), for Allah most High has ordained the endurance of the world until the time of its dissolution, and He has rendered the earning of the servants the cause of this endurance and order, whereas disregarding it (earning) leads to the ruin of this order, and that is something disallowed. ${ }^{62}$

On the other hand, Islam prohibits all forms of transgression, whether in earning, trading, leadership, or married life. The Qur'an says: "Verily Allah will not deal unjustly with man in aught: It is man that wrongs his own soul." ${ }^{93}$

\section{Proof of the Permissibility and Recommendation of Earning}

Al-Shaybani stated, "our evidence on the permissibility and recommendation for earning is what the Qur'an states: 'But Allah hath permitted trading and forbidden riba (usury)." "'64

The Qur'an states: 'O ye who believe! When ye deal with each other, in transactions involving future obligations in a fixed period of time, reduce them to writing. ${ }^{65}$ And the Qur'an states, 'Eat not up your property among yourselves in vanities: but let there be amongst you traffic and trade by mutual good-will. ${ }^{66}$ This verse warns against vanities in someone's wealth through stealing, usury, gambling, oppression and deception. The acquisition of property amongst yourselves should be via business. ${ }^{67}$

"Some of these verses indicate the permissibility of earning, while others constitute a recommendation for engaging in trade. Whoever says these verses do not indicate the permissibility of trade, his understanding contradicts the meaning of the text; this is because the verses deals with the issues that are common even to the lay man, for example the issues of debts, witnesses and writing agreements." ${ }^{68}$

Indeed, the statements in these verses should be understood as people use them in their speech. Surely the Shari'ah of Allah is revealed to us according to the ability of our understanding. The terms buying and selling in the verses indicate 
the real meaning of earning; it is not metaphorical. The statement carries the real meaning; it can only be turned into a metaphor when there is proof, such as in the following verse: "Verily, Allah has purchased of the believers their persons and their goods; for theirs (in return) is the garden (of Paradise)." ${ }^{99}$ Since God promises a just reward only to those who fight in the cause of eternal salvation, the latter cannot be attained through anything other than our sincere redemption or suffering, not any commercial transaction. ${ }^{70}$ This verse referencing buying and selling between Allah and the believers is therefore metaphoric.

The Prophet said: "No one has ever eaten any food that is better than eating what his hands have earned. And indeed, the prophet of Allah Dawud would eat from the earning of his hands." 71 This hadith indicates what Allah says: "Eat of the good things which We provided for you." 72 With certainty we are on solid ground when we assert that acquisition of wealth is the sunnah of all the prophets. ${ }^{73}$ Earning is the best provision one can acquire in this world and in the hereafter. ${ }^{74}$ Imam 'Ala al-Din 'Ali ibn al-Lubadi stated:

It was said to a wise man, 'What are the best (types) of earnings?' He said, 'As for the (best) earnings in this world, these are seeking of the lawful in order to avoid being in need, the taking from it after worship and sending forward its surplus as a provision for the Day of resurrection. As for the best earnings of the Hereafter, it is knowledge that you have disseminated, a good deed that you have done, and a good practice sunnah that you have revived.' It was then said (to him), 'What are the worst (types) of earnings?' He said, 'As for the earnings in this world, these are the unlawful that you have amassed and spent on iniquities, and which you leave behind for those who do not obey Allah. As for worst (type) of earnings in the Hereafter, these are a right that you denied, a sin that you committed and an evil custom that you actualised. ${ }^{175}$

\section{The Position and Benefits of Earning in Islamic Finance and Economics}

Islam provides guidance and a prescribed set of rules for all aspects of human life, including the economic. In economics and finance, Islam deals with trading (i.e. buying and selling), contracts and the funding of wealth (i.e. zakat). Muslims are vulnerable under conventional finance wherever they are subjected to it. Nevertheless, efforts by Muslims to implement Islamic finance still leave much to be desired; many transactions are still not free from riba, deception and ambiguities. Tawarruq is a good example of this. This concept means the buying of an item on credit on a deferred-payment basis and then immediately reselling 
it for cash at a discounted price to a third party. Riba enters into this transaction as a result of the creditor selling the item to the buyer with a deferred payment set at a higher amount than the original sale price. ${ }^{76}$ Although this contract is called Islamic, its actual practice is against the teachings of Islam. As a result of this ambiguity, the wealth generated from this type of earning is not in line with the requirements of an authentic transaction and not, therefore, a good way of financing any charitable institutions or individuals. Instead, there are other ways in which this can be achieved. The Qur'an says:

Alms are for the poor and the needy, and those employed to administer the (funds); for those whose heart have been (recently) reconciled (to Truth); for those in bondage and in debt; in the cause of Allah, and for the wayfarer. ${ }^{77}$

In farming, for example, a farmer has to set aside a part of the harvest for alms giving. Likewise, a proportion of all provisions and assets owned by an individual above a fixed amount must be paid as zakat annually. In addition, spoils of war are earnings with benefits extending even to those who did not participate in the battle. The prophet's share and the share of others were fixed. The Qur'an says:

And know that out of all the booty that ye may acquire (in war), a fifth share is assigned to Allah, and to the Messenger, and to near relatives, orphans the needy, and the wayfarer... ${ }^{78}$

In the same vein, earnings can also be lawfully taken from: unbelievers as a result of treaties, the people of reconciliation, lands under covenant and reconciliation, and the wealth of an inheritance not entitled to anyone. Moreover, taxes levied on land, people, gifts, donations, bequests, and labour are also valid forms of earning. There are also modern types of income, including the sale of petroleum, gas and farming, in addition to the provision of services (for example, electricity and means of communication) that also constitute valid earnings. These additional forms of earning should be distributed by the government of a country to those who work in the defence of religion, for example Muslim judges and other pious persons. ${ }^{79}$

The foregoing discussion has illustrated the great achievements of Islamic civilisation during the second century $\mathrm{AH}$. These achievements came in different forms, such as the earning of wealth from farming, carpentry and trading in merchandise. These activities continue to the present day. 


\section{Conclusion and Policy Recommendations}

The purpose of life in this world is to gain spiritual and material earnings. The Qur'an says, "I have only created the Jinn and Men, that they may serve Me." ${ }^{80}$ The positive aspects of earning are commendable, while its negative aspects should be avoided as harmful in both this world and the hereafter. Islam encourages hard work in the context of earning a livelihood, prohibiting laziness and begging, except by someone who finds himself in a critical condition. The prophets, while performing numerous miracles, also earned their livelihoods, notably as shepherds. They also practiced metal work, carpentry, and farming. Today, development may be achieved through lawful earning, even by a person who is not a Muslim. Transgression through unlawful means, on the other hand, destroys progress and brings backwardness. In this way, earnings should not be underrated; any form of permissible earning may be encouraged accordingly. In order to achieve success in both lives, a person must earn properly. This paper recommends that:

- Different types of legal earning should be encouraged, especially farming, which has a direct relation with every aspect of life.

- The prophets demonstrate to the ummah that a livelihood does not come by itself.

- Islamic institutions should inculcate the true teachings and ethics of earning in their programmes.

\section{Notes}

* Ismail Ya'u Abubakar is a PhD Candidate at the Centre for Advanced Studies on Islam, Science and Civilisation (CASIS), University Technology Malaysia (UTM).

** Tatiana Danisova is a History Professor at the Centre for Advanced Studies on Islam, Science and Civilisation (CASIS), University Technology Malaysia (UTM).

*** Suleiman Mohammed Hussein Boayo is a Senior Lecturer in History and Civilisational Studies at the Centre for Advanced Studies on Islam, Science and Civilisation (CASIS), University Technology Malaysia (UTM).

1. Muhammad bin al-Hasan bin Farqad, also known as Abu Abd Allah al-Shaybani was born in $132 \mathrm{AH}$. It is agreed that his place of birth was Bawasit, one of the cities in Iraq. He studied in Kufah, which was a centre of knowledge and learning. He mastered a variety of sciences including figh, Arabic, hadith and grammar. He travelled to many places in search of knowledge, including Madinah, Makkah, Sham and Yaman. He learned from scholars and many also studied under him. Famous among his teachers was Abu Hanifa, who groomed 
him and instilled in him the zeal for learning. Imam Malik and Abu Yusuf were also among his teachers. His students included Imam al-Shafi 'i, Abu Sulaiman al-Jurjani and others. Among his contemporaries were Qasim bin Sallam alHarawi, Ali bin Hasn al-Razi and Imam al-Shafi 'i. He began his career during the time of caliph Imam Ali and was appointed as chief judge during the reign of three caliphs: Ibrahim al-Mahdi, Abdullahi al-Hadi and Harun al-Rashid. Among his publications were al-Mubsut, al-Jami ' al-saghir and al-Sayar al-saghir. AlShaybani wrote a book on al-kasb because he was asked to publish a book on the ascetic concepts of zuhd and caution (al-wara). He replied by saying, "I published a book on buying and selling." Then he started writing on earning but passed away before completing the work. Al-Shaybani died at $182 \mathrm{AH}$, see, Muhammad bin al-Hasan al-Shaybani, Kitab al-Kasb (Halba: Dar al-Kutb alIlmiyah, 1997), 12; see also, Umar bn Abd al-Aziz al-Bukhari, Sharh al-Jami al-Saghir (Beirut: Dar al-Kutb al-Ilmiyah, 2006), 25.

2. Al-Shaybani, Kitab al-Kasb, 70.

3. Muhammad bin Mukrim bin Ali and Jamal al-Din Bin Manzur, Lisan al-Arab (Beirut: Dar al-Sadr, 1414 AH), 716.

4. Wizarat al-Awqafwa al-Shu' un al-Islamiyyah Kuwait, al-Mausu 'ah al-Fiqhiyah al-Kuwaitiyyah (Kuwait: Ministry of Islamic Affairs Kuwait, 1427 AH), 5.

5. Al-Baqarah, 2:286.

6. Ibn Manzur, Lisan al-Arab, 716.

7. Ali bn Muhammad al-Sayyid al-Jurjani, Mu'jam al-Ta'rifat (Cairo: Dar alFadilah, n.d.), 154.

8. Muhammad bin Saleh bin Muhammad al-Uthaimin, al-Qaul al-Mufid Ala Kitab al-Tauhid (Saudi Arabia: Dar al-Ibn al-Jauzi, 1424 AH), 253.

9. Hans Wehr, The Hans Wehr Dictionary of Modern Written Arabic (New York: Snowball Publishing, n.d.), 825.

10. Derrick G. Hanson, Dictionary of Banking and Finance (London: Pitman Publishing Ltd, 1985), 241.

11. Abu Ammar Yasir al-Qadhi, 'The Importance of Halal Sustenance,' Mission Islam. Available at: http://www.missionislam.com/knowledge/halaalsustenance. html. (Accessed on: 30 November 2011).

12. Al Islamiyya, Al-Mausu 'ah al-Fiqhiyah, 236.

13. Ibid., 236.

14. Adi Setia and Nicholas Mahdi Lock, Right Livelihood and the Common Good Kasb Tayyibwa-Maslahah 'Ammah (Kuala Lumpur: IBFIM, 2013), 24.

15. This translation is from: The Holy Qur'an: English Translation of the Meanings and Commentary (Madinah: King Fahd Holy Qur'an Printing Complex, 1419 $\mathrm{AH})$.

16. Sayyid Sabiq, Fiqh al-Sunnah (Beirut: Dar al-Kutb al-Arabi, 1977), 46.

17. Abu Qasim Muhammad bin Ahmad al-Kalbi al-Garnati, al-Qawanin al-Fiqhiyah (Riyad: Markaz al-Turath lil-Barmajiyah, 2013), 165.

18. Al-Shaybani, Kitab al-Kasb, 70.

19. Nasir Khasru, Mu'jam al-Faz al-Qur'an (Tehran: Islamic Publication, 2013), 240-3.

20. Muhi al-Sunnah, Abu Muhammad Husain bin Mas'ud al-Bagawi, Tafsir alBagawi (Beirut: Dar Ihya' al-Turath al-Arabi, 1420 AH), 142. 
21. Al-Baqarah, 2: 286.

22. Mahmud bin Amr bin Ahmad al-Zamakshari, al-Kashaf an-haqa'q Gawamid al-Tanzil (Beirut: Dar al-Kutb al-Arabi, 1407 AH), 332.

23. Muhammad Ali al-Sabuni, Safwat al-Tafasir (Cairo: Dar al-Sabun li tiba 'ahwa al-Nashr, 1997), 163.

24. Muhammad bin Jarir al-Tabari, Jami 'al-Bayanan Tafsir al-Qur'an, ed. Abdullahi bin Abd-al-Muhsin al-Turki (n.p.: Dar al-Hijrat li tiba'ahwa al-Nashrwa alTauziwa al-'lan, 2001), 154.

25. Abdullahi Ibn Abbas, Tanwir al-Miqbas min Tafsir Ibn Abbas (Beirut: Dar alKutb al-Ilmiyah, $817 \mathrm{AH}), 42$.

26. Al-Baqarah, 2:286.

27. Wahb bin Mustapaha al-Zuhail, Al-Tafsir al-Munir fi al-Shariah wa al-Aqidah wa al-Manhaj (Damascus: Dar Fikhr al-Mu'asir, 1418 AH), 153.

28. Mufti M. Mukarram Ahmed, Encylopedia of Islam (Kuala Lumpur: Crescent News Sdn. Bhd, 2007), 19-21.

29. Setia and Lock, Right Livelihood and the Common Good, 349.

30. Ali bin Muhammad bn Ali al-Jurjani, Kitab al-Ta 'rifat (Beirut: Dar al-Khutub al-Ilmiyah, 1983), 10.

31. Messengers are the best of Allah's creation, but He does not send down to them provision and wealth. He makes them work hard in this world by earning their living. If Allah wills, He may send down to them wealth from the heavens.

32. Taha, 20: 117.

33. Hassan al-Shaybani, Kitab al-Kasb, 74-5.

34. Spahic Omer, 'Islam Rejects Excessive Asceticism and Monasticism,' Islamicity. Available at: http://www.islamicity.com/articles/printarticles.asp?ref=IC12115338\&p=1. (Accessed on: 13 October 2017).

35. Hassan al-Shaybani, Kitab al-Kasb, 75.

36. Pragyandeepa, 'Role of Agriculture in the Economic Development of a Country,' Economics Discussion. Available at: http://www.economicsdiscussion.net/ economic-development/role-of-agriculture-in-the-economic-development-of-acountry/4652. (Accessed on: 30/12/2016).

37. Narrated by al-Hakim in al-Mustadarak 2:596. The hadith chain of narration is weak, as stated by al-Hafiz Ibn Hajar in Fathu al-Bari 4:306, in Kitab al-Buyu.

38. Al-Shaybani, Kitab al-Kasb, 76. There is wisdom in earning a living by hand, working using our hands makes one experience some difficulties in life. In the process, one will also experience the sweetness of consuming halal provision to a greater degree than others.

39. Ibid., 76-7.

40. Md. Habibu al-Rahman, 'Bayt al-Mal and its Role in Economic Development: a Contemporary study,' Turkish Journal of Islamic Economics 2, no. 2, (2015): 7-17.

41. Saba', 34:10.

42. An-biya', 21:80.

43. Al-Shaybani, Kitab al-Kasb, 77.

44. Narrated by Muslim in his Sahih, 15:135, in Kitab al-Fada'il and Ibn Majah, 2:727, in Kitab al-Tijarat.

45. Narrated by al-Bukhari, 4;441, Kitab al-Ijarah. The Prophet Muhammad who 
was sent to humanity, reared animals, as did the rest of the messengers. This indicates that livestock farming was essential in the past. See, Al-Shaybani, Kitab al-Kasb, 77-8.

46. Alison Young, 'Introduction to Carpentry'. Available at: https://alison.com/ courses/Introduction-to-Carpentry. (Accessed on: 6 January 2017).

47. Al-adam the plural of adim is clean or unclean leather, see: Muhammad ibn Muhammad ibn Abd al-Razaq al-Zubaydi, Taj al-Arus, vol. 181; and 'Adamiyu who is selling the leather. IbnAthir, in Ansab, 1: 41.

48. A town four miles away from Madinah, see, al-Shaybani, Kitab al-Kasb, 80 .

49. Ibid., 78-80.

50. http://www.businessdictionary.com/definition/partnership.html.

51. Al-Jumu'ah, 62:10.

52. Al-Baqarah, 2:267; al-Shaybani, Kitab al-Kasb,70.

53. Abu Muhammad Husain bn Mas'ud al-Bagawi, Muhi al-Sunnah (Beirut: Dar Ihya' al-Turath al-Arabi, $1420 \mathrm{AH}), 142$.

54. Al-Shurah, 42:30.

55. Al-Maidah, 5:38.

56. An-Nisa, 4:111.

57. An-Nisa, 4:112; al-Shaybani, Kitab al-Kasb, 80-1.

58. Ibid., 140 .

59. Umar bin Faihan al-Marzuqi, 'al-Nishat al-Iqtisadi min Manzur Islami.' Available at: https://www.google.com/webhp?sourceid=chrome-instant\&ion. (Accessed on: 14 May 2016).

60. Abu Hamid Muhammad bin Muhammad al-Ghazali, Ihya' Ulum al-Din (Beirut: Dar al-Ma'rifah, n.d.), 62.

61. Maryam, 19:25.

62. Setia and Lock, Right Livelihood and the Common Good, 43.

63. Yunus, 10:44.

64. Al-Baqarah, 2: 276. The word riba is derived from the Arabic root raba which means "to increase" and refers to the practice of lending money at an exorbitant (and therefore unlawfully high) rate of interest. The technical definition of riba is any material gain or advantage derived through unjust means - such as cheating, bribing, corrupt exploitation of influence or authority for self-advantage, deception in trade, speculative transactions, or living off the sweat of others. Riba is of two types: riba al-fadl, which occurs when there are transactions where items capable of riba (mal al-ribawi) are exchanged or where there is an increase in either item over another if they differ in quality; and riba al-nasi 'ah (delayed payment usury), a form of usurious transaction that occurs if there is a sale where both items are properties subject to usury (mal al-ribawi), but only one of the items is received at the time and place of the sale and the other items were received at a later date. Aly Khorshid, Islamic insurance - A modern approach to Islamic Banking (London: Routledge Curzon, 2014), 34-5. Imran N. Hosein, The Importance of Prohibition of Riba in Islam (Kuala Lumpur: Umma Vision Resources, 1947), 44.

65. Al-Baqarah, 2:282.

66. An-Nisa, 4: 29.

67. Al-Shaybani Kitab al-Kasb, 86. 
68. Ibid., 85 .

69. Al-Taubah, 9:111.

70. See the Holy Qur'an English translation, 536.

71. Narrated by Imam al-Bukhari in his Sahih, 4: 303 in Kitab al-Buyu .

72. Al-A'raf, 7:160.

73. Al-Shaybani, Kitab al-Kasb, 86-87.

74. Ibid.

75. Setia and Lock, Right Livelihood and the Common Good, 289.

76. Abbabs Miraclchtor, Zamir Iqbal, An Introduction to Islamic Finance: Theory and Practice (Singapore: John Wiley \& Sons: 2011).

77. Al-Taubah, 9:60.

78. Al-Anfal, 8:41.

79. Sheikh Othman bin Fodiyo, Selected Writings of Sheikh Othman bn Fodiyo (Gusau: Iqra publishing House, 2013), 224-7.

80. Al-Zariyat, 51: 56. 